\title{
Does wing dimorphism affect mobility in Metrioptera roeselii (Orthoptera: Tettigoniidae)?
}

\author{
DOMINIK PONIATOWSKI and THOMAS FARTMANN
}

\begin{abstract}
Department of Community Ecology, Institute of Landscape Ecology, University of Münster, Robert-Koch-Straße 28,
\end{abstract} 48149 Münster, Germany; e-mail: poni@uni-muenster.de

\begin{abstract}
Key words. Orthoptera, Tettigoniidae, Metrioptera roeselii, bush-cricket, dispersal, macroptery, mark and recapture, movement pattern
\end{abstract}

\begin{abstract}
Range shifts are among the most conspicuous effects of global warming. Marked changes in distribution are recorded both for highly mobile species of insects, which are capable of flight, and wing-dimorphic species with predominantly short-winged individuals. One of these species is the bush-cricket Metrioptera roeselii, which occasionally produces long-winged individuals. However, there is little known about the locomotory behaviour of wing-dimorphic insects. Yet to be able to predict potential range shifts it is necessary to know the dispersal potential of macropters. Therefore, an experiment was conducted in which individually marked M. roeselii were released at four sites. Different movement parameters, such as daily movement, activity radius, dispersal range, net displacement and crowding rate, were calculated. The statistical analyses showed that the movement of long-winged and shortwinged individuals did not differ, but the percentage of individuals that were not seen again was twice as high for long-winged bushcrickets. These results suggest that most of the long-winged individuals that were seen again did not fly; i.e., they had the same basic mobility as the short-winged individuals. However, the comparatively low number of long-winged individuals that were seen again suggests that at least some macropters are long-distance dispersers, which is relevant for the dispersal process. The comparison of sexes showed that males were significantly more mobile than females. This sex-specific locomotory behaviour in M. roeselii might depend on a complex series of social interactions and physiological conditions.
\end{abstract}

\section{INTRODUCTION}

Global warming is likely to have highly diverse effects on species. Range shift is one example. Among insects, the highly mobile Odonata show strong responses (Hickling et al., 2005). However, range shifts are frequently recorded for taxa with intermediate dispersal abilities, such as most butterflies (Parmesan et al., 1999) and even insect groups with many flightless species, like Orthoptera (Reinhardt et al., 2005). In addition to species with passive dispersal (Fartmann, 2004) there are species that have a high flight ability (Kleukers et al., 1996; Kočárek et al., 2008) or a well developed wing dimorphism (Simmons \& Thomas, 2004; Hochkirch \& Damerau, 2009).

This study focuses on the latter dispersal strategy. Wing dimorphism means that in addition to the predominantly short-winged individuals (brachypters), long-winged individuals (macropters) are also regularly produced (Harrison, 1980; Zera \& Denno, 1997). Until the mid-20th century, macropters of wing-dimorphic Orthoptera were rarely recorded in Europe (Ramme, 1931). Currently macropters occur significantly more frequently (Gardiner, 2009) and populations with more than $20 \%$ macropters are no longer a rarity (Gardiner, 2008; Poniatowski \& Fartmann, 2008). Climate change with increasing temperatures promotes the survival of young nymphs and leads to high population densities (Poniatowski \& Fartmann, 2011). Crowding is assumed to be the main driver of macroptery (Poniatowski \& Fartmann, 2009, 2011). Hence, many researchers assign macropters an important role in dispersal (Simmons \& Thomas, 2004; Gardiner 2009; Hochkirch \& Damerau, 2009).

Although the mobility of many species of Orthoptera has been studied (Kindvall et al., 1998; Leisnham \& Jamieson, 2002; Hein et al., 2003; Gardiner \& Hill, 2004; Diekötter et al., 2005), nothing is known about the locomotory behaviour of macropters. Indeed, observations on the flight of long-winged individuals suggest that this morph is much more mobile than its short-winged conspecifics (Higaki \& Ando, 2003; Smith, 2007; Gardiner, 2008). This assumption is supported by indirect evidence such as genetic analyses and records of single macropters occurring far from the nearest population (Hochkirch \& Damerau, 2009; Wissmann et al., 2009).

The factors determining dispersal are highly complex. For instance, corridors (Berggren et al., 2002), type of habitat (Hein et al., 2003, Schuhmacher \& Fartmann, 2003), landscape structure (Diekötter et al., 2007), management (Berggren, 2004) and population density (Brunzel, 2002) can promote individual movement. Sex (Mason et al., 1995; Walters et al., 2006) and wing morph (Simmons \& Thomas, 2004; Hochkirch \& Damerau, 2009) may also have a strong effect on mobility and dispersal. However, how and to what extent wing morphs differ in their locomotory behaviour is still unclear. To be able to predict potential range shifts it is necessary to know the dispersal potential of macropters.

Therefore, a study was designed to investigate the locomotory behaviour of a wing-dimorphic insect: Metrioptera roeselii, a widespread bush-cricket (Maas et al., 
2002), which regularly produces long-winged individuals (Poniatowski \& Fartmann, 2009, 2011). This species is an ideal model system for studying wing dimorphism as it is currently expanding its range in large parts of central Europe (Simmons \& Thomas, 2004; Wissmann et al., 2009). To compare the locomotory behaviour of longand short-winged individuals, a marking experiment was conducted. Individually marked $M$. roeselii were released at four sites with suitable habitats and a similar vegetation structure. Different movement parameters were calculated. The dispersal potential of long-winged $M$. roeselii was evaluated and its relevance for range expansion discussed.

\section{MATERIAL AND METHODS}

\section{Study species}

Roesel's bush-cricket Metrioptera roeselii (Hagenbach, 1822) (Orthoptera: Tettigoniidae) is a medium-sized bush-cricket, 13-26 mm in length and predominantly short-winged (Marshall \& Haes, 1988). However, in recent years long-winged individuals (macropterous form), which are capable of flight, have been regularly recorded (Gardiner, 2009; Poniatowski \& Fartmann, 2011). M. roeselii is a typical species of agricultural landscapes colonising a variety of different habitats (e.g., grassland, fallow land and road verges) (Marshall \& Haes, 1988; Kleukers et al., 1997) in which the vegetation is of intermediate height (Poniatowski \& Fartmann, 2005). Population densities reach values between 0.7 and 11 adults $/ 10 \mathrm{~m}^{2}\left(N_{\text {studies }}=5\right)$ (reviewed by Ingrisch \& Köhler, 1998).

\section{Study area}

The marking experiment was carried out in the military training area "Handorf Ost" (HE), located in north-western Germany $\left(51^{\circ} 59^{\prime} \mathrm{N} / 7^{\circ} 43^{\prime} \mathrm{E}\right)$. The study area of about 320 ha is a plain ( $\sim 55 \mathrm{~m}$ a.s.1.), which is characterized by a patchwork of different nutrient-poor habitats such as semi-dry, mesic and wet grassland (Fleischer et al., 2010). Other typical habitats are hedges, shrubbery and small forests.

\section{Experimental design}

During the summer of 2009, a total of 288 brachypterous (short-winged) and macropterous (long-winged) individuals of $M$. roeselii were collected at five sites close to the study area. All of them were marked with reflective material (3M Scotchlite 7610 high gain) so that they could be located at night by using a headlamp (Heller \& von Helversen, 1990). Marking was done by gluing small pieces $(2.5 \mathrm{~mm}$ in diameter) of reflective tape on the paranota (Kindvall, 1999; Fig. 1). This modified marking technique was used because bush-crickets that were marked by fixing the reflective tape around the hind femur (Heller \& von Helversen, 1990) tried to bite off their hind legs. In addition, individuals of $M$. roeselii were marked individually with honey-bee markers on the dorsum of the pronotum (Ingrisch \& Köhler, 1998; Kindvall, 1999; Fig. 1). Uhu instant adhesive without solvent and pungent vapours, was used as the adhesive, as recommended by Ingrisch \& Köhler (1998). All individuals of $M$. roeselii were captured just before the start of the experiment and kept individually in cool boxes before and after marking (Hein et al., 2003; Diekötter et al., 2005, 2007).

For the marking experiment four sites (HE1-4) were chosen all of which were unimproved grassland with a similar vegetation structure and a suitable habitat for $M$. roeselii. The species was present at these sites at low densities (less than 1 adult/10 $\mathrm{m}^{2}$ ). The marked animals were released at these sites in the summer of 2009 at $10.30 \mathrm{pm}$ (19 July at HE1-HE3 and 5

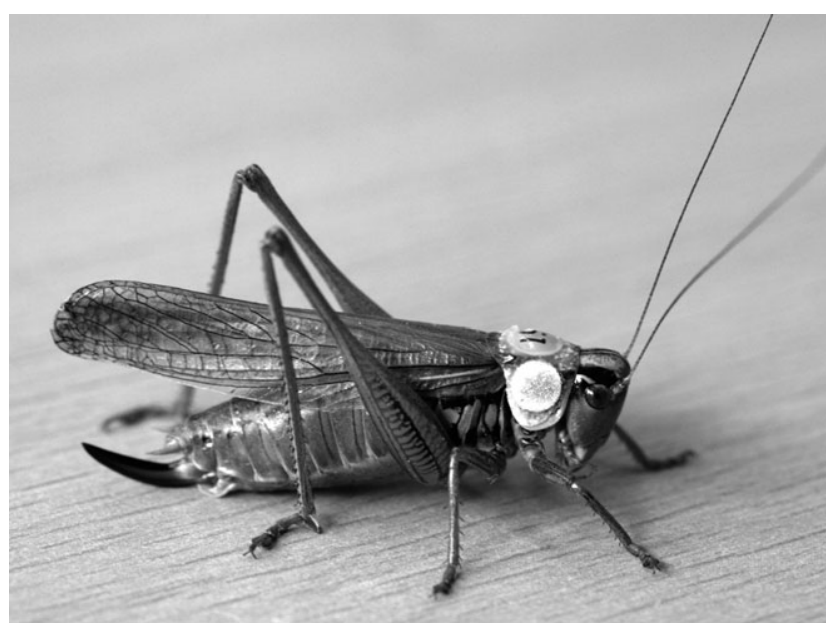

Fig. 1. Long-winged individual of Metrioptera roeselii ( 9 ), marked with reflective material on the paranota and a numbered plastic plate on the dorsum of the pronotum.

August at HE4). At each site 72 marked individuals of $M$. roeselii (36 brachypters, 36 macropters) were released within a radius of $1 \mathrm{~m}$ around each release point. On the following 11 nights, using headlamps the area within a radius of $300 \mathrm{~m}$, and occasionally within a radius of $500 \mathrm{~m}$, around each release point was searched carefully for marked individuals (Diekötter et al., $2005,2007)$. No marked individuals were found outside the 300 $\mathrm{m}$ radius during the entire study period. The maximum distance a marked individual was found from a release point was $183 \mathrm{~m}$. The position of each individual that was seen again was recorded using differential GPS (Garmin GPS-60 with an external RTCM-decoder), which has an accuracy of $\sim 1.5 \mathrm{~m}$. During this procedure care was taken not to disturb the animals. Long-term activity of the bush-crickets was measured weekly for an additional two weeks.

\section{Statistical analyses}

The linear movement parameters listed in Table 1 were calculated. To compare means of different movement parameters between sexes, an independent $t$ test for unpaired samples and a dependent $t$ test for paired samples were used. The relationship between the number of individuals that were not seen again (proportional response variable) and wing morph were analyzed using a binominal generalized linear model (GLM) with a twovector response variable (for details see Crawley, 2007). Generalized linear mixed-effects models (GLMM: lmer, Bates et al., 2008) were conducted to analyze the effect of wing morph (brachypters vs. macropters) and sex (females vs. males) on the locomotory behaviour of $M$. roeselii. Origin of the bush-crickets and release site were random factors in all GLMMs. A quasiPoisson error structure was used to counteract over-dispersion. The significance of the predictor variables were assessed using likelihood ratio tests (Type III test).

Statistical analyses were performed using R-2.9.0 (R Development Core Team, 2009) and SPSS 11.5 statistical packages.

\section{RESULTS}

\section{Percentage of the marked individuals that were seen again}

The percentages of marked individuals that were seen again at HE1, HE3 and HE4 were high (Fig. 2). Although there were some sharp declines on rainy and sunless days, $35 \%$ or more of the released individuals were seen on the 
TABLE 1. Definitions of the movement parameters.

\begin{tabular}{|c|c|c|c|}
\hline Movement parameter & Abbreviation & Definition & Source \\
\hline Mean daily movement ${ }^{\mathrm{a}}$ & MDM & $\begin{array}{l}\text { arithmetic mean of all straight-line distances* between consecutive } \\
\text { daily records for an individual, even if the record is incomplete }\end{array}$ & $1,2,3$ \\
\hline Maximum daily movement ${ }^{\mathrm{a}}$ & MaxDM & greatest distance between the records on two consecutive days & 4 \\
\hline Mean activity radius & MAR & $\begin{array}{l}\text { arithmetic mean of all straight-line distances between release point } \\
\text { and all further observation points for one individual }\end{array}$ & 1,3 \\
\hline Dispersal range ${ }^{\mathrm{b}}$ & DR & greatest distance between any two records for one individual & 1,3 \\
\hline Net displacement rate & NDR & $\begin{array}{l}\text { distance between release point and the point at which it was last seen } \\
\text { divided by the number of days between release and the last sighting }\end{array}$ & 2 \\
\hline Crowding rate & $\mathrm{CR}$ & $\begin{array}{c}\text { distance between the release point and the position of the released } \\
\text { individual after } 3 \text { days divided by } 3\end{array}$ & 4 \\
\hline
\end{tabular}

${ }^{a}$ To avoid a possible distortion of the data due to translocation (Heidinger et al., 2009) and/or crowding effects (Brunzel, 2002) the calculations do not include the daily movement recorded in the first two days.

${ }^{\mathrm{b}}$ Caution: DR depends strongly on the duration of the study, which in this case was a maximum of 25 days.

* Only individuals with at least 2 straight-line distances are included in the calculation.

1 - Diekötter et al. (2005); 2 - Diekötter et al. (2007); 3 - Samietz \& Berger (1997); 4 - Self produced.

11 th day. One week later the percentages were 20 to $30 \%$. The day-to-day percentages (from the 2 nd day of monitoring) were $\geq 85 \%$ until the 11 th day. By contrast, the percentage seen again at HE2 was rather low (Fig. 2). On the fifth day only $18 \%$ of the released individuals were seen. Therefore, the mobility recorded at HE2 was not included in the analysis.

The percentage of individuals not seen again differed significantly between wing morphs (GLM: Estimate = 1.0953; $\mathrm{SE}=0.1525 ; \mathrm{Z}=7.184 ; \mathrm{P}<0.001 ;$ Pseudo $\mathrm{R}^{2}$ $[$ McFadden $]=0.28)$ : for long-winged $(50 \% \pm 12.3 \mathrm{SE})$ bush-crickets the mean percentage was twice that of short-winged (25.2\% \pm 9.9 SE) individuals (Fig. 3).

\section{Patterns of movement}

The results of the GLMMs revealed that long-winged and short-winged individuals did not differ in their locomotory behaviour (Table 2 ). In only one of the six move- ment parameters the short-winged individuals that were seen again had a higher dispersal range than long-winged individuals. In contrast, sexes differed in all the movement parameters (Table 2). Males were significantly more mobile than females (Table 2 and Fig. 4). Mean daily movement ranged from 1.5 to $17 \mathrm{~m}$ (mean: $7.3 \mathrm{~m} \pm 0.4$ $\mathrm{SE})$ for females and from 3.5 to $25.5 \mathrm{~m}$ (mean: $9.9 \mathrm{~m} \pm$ $0.5 \mathrm{SE}$ ) for males (Fig. 4a). In both sexes, the mean maximum daily movement was approximately twice as high as the mean daily movement, ranged from 3 to 54.6 $\mathrm{m}$ (mean: $13.2 \mathrm{~m} \pm 1.1 \mathrm{SE}$ ) for females and from 4.5 to $73.1 \mathrm{~m}$ (mean: $22.3 \mathrm{~m} \pm 1.7 \mathrm{SE}$ ) for males (Fig. $4 \mathrm{~b}$ ). The maximum value of the mean activity radius and dispersal range was $144.4 \mathrm{~m}$ for a long-winged female and $126.8 \mathrm{~m}$ for a short-winged male. However, the means of both these parameters were much lower (Fig. $4 \mathrm{c}$ and d).

Males were significantly more mobile in the first two days following their release than in the following days

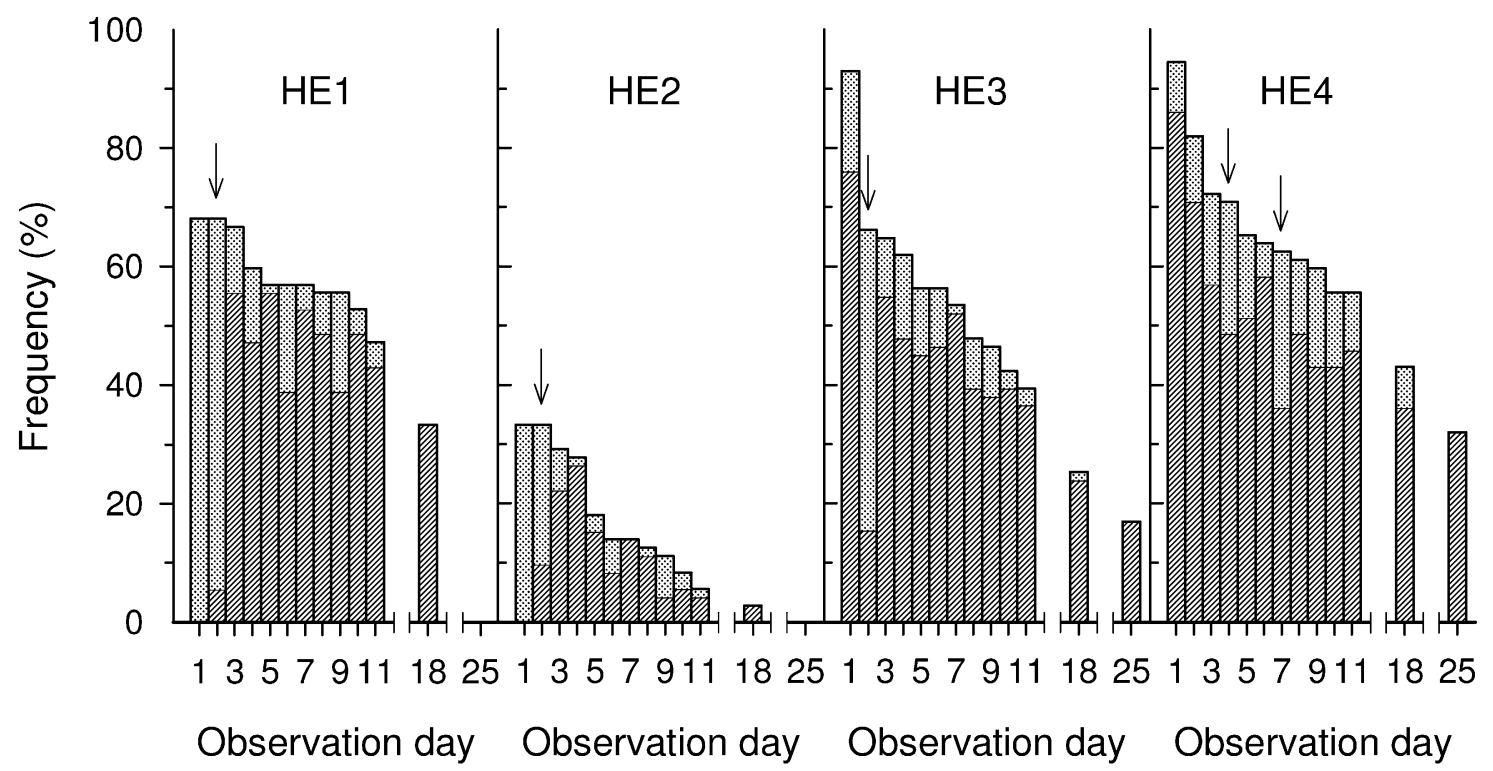

Fig. 2. Percentages of marked individuals that were seen again (dark grey) and those seen again only on one of the following days (grey). The number of individuals released was $\mathrm{n}=72(=100 \%)$ at each of the four sites (HE1-4). Arrows indicate rainy days with more than $20 \mathrm{~mm}$ precipitation or sunless days with less than 1 hour sunshine. For HE1 and HE2 there is no data for the first day, because the differential GPS was defective on that day. 


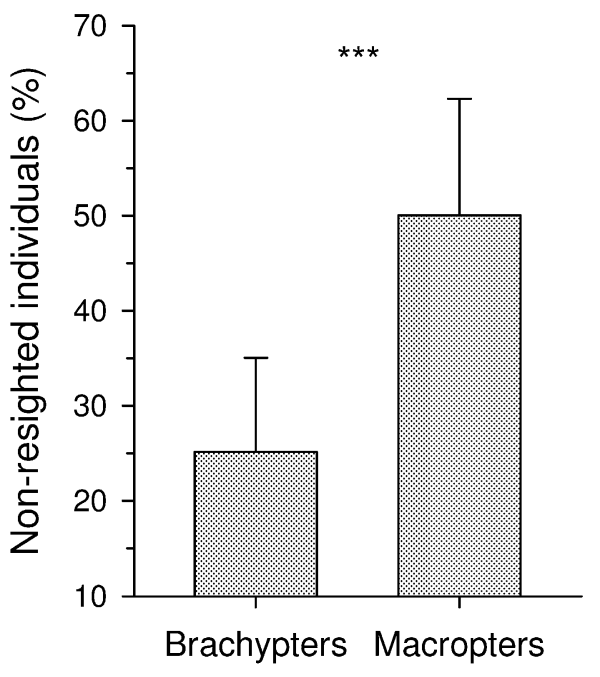

Fig. 3. Percentage of individuals not seen again (mean $\pm \mathrm{SE}$ ); calculated from the 2 nd day of the experiment $\left(n_{\text {release points }}=4\right)$. Differences were analyzed using a binomial generalized linear model (GLM): ${ }^{* * *} P<0.001$. For details see material and methods.

(Fig. 5a). The same pattern was recorded for females, but it was less marked: females on the first day were distinctly more mobile than in the following days (Fig. 5b). Both the net displacement and crowding rate differed between the sexes (Fig. 6). While net displacement rate was low and ranged from 0.4 to $9.8 \mathrm{~m}$ for females (mean: $1.9 \pm 0.4 \mathrm{SE}$ ) and from 0.1 to $19.4 \mathrm{~m}$ for males (mean: 3.1 $\pm 0.4 \mathrm{SE})$, crowding rate was much higher and ranged from 1.3 to $24 \mathrm{~m}$ for females (mean: $6.6 \pm 0.8 \mathrm{SE}$ ) and from 0.5 to $38.8 \mathrm{~m}$ for males (mean: $8.7 \pm 1 \mathrm{SE}$ ).

\section{DISCUSSION}

\section{Percentage of the marked individuals that were seen again}

The percentages of marked individuals seen again are comparable with those recorded in other studies on Orthoptera (Heller \& von Helversen, 1990; Kindvall et

TABLE 2. Statistics of GLMM (quasi-Poisson): Relationships between different movement parameters (response variables) and several predictor variables (sex and wing morph). Nonsignificant predictors are not shown. For abbreviations see Table 1.

\begin{tabular}{lcccc}
\hline & Estimate & SE & $T$ & $P$ \\
\hline $\begin{array}{l}\text { MDM } \\
\quad \text { sex: males }\end{array}$ & 0.3090 & 0.2430 & 1.272 & $<0.0001$ \\
$\begin{array}{l}\text { MaxDM } \\
\quad \text { sex: males }\end{array}$ & 0.4744 & 0.5214 & 0.91 & $<0.0001$ \\
$\begin{array}{l}\text { MAR } \\
\quad \text { sex: males }\end{array}$ & 0.3958 & 0.7712 & 0.5133 & $<0.0001$ \\
$\quad$ DR & & & & \\
$\quad$ sex: males & 0.5331 & 0.7620 & 0.6996 & $<0.0001$ \\
$\quad$ wing: macropters & -0.4441 & 1.1763 & -0.3776 & $<0.0001$ \\
$\quad \begin{array}{l}\text { NDR } \\
\quad \text { sex: males }\end{array}$ & 0.5434 & 0.3069 & 1.771 & $<0.0001$ \\
$\quad$ CR & & & & \\
$\quad$ sex: males & 0.3468 & 0.4460 & 0.7776 & $<0.0001$ \\
\hline
\end{tabular}

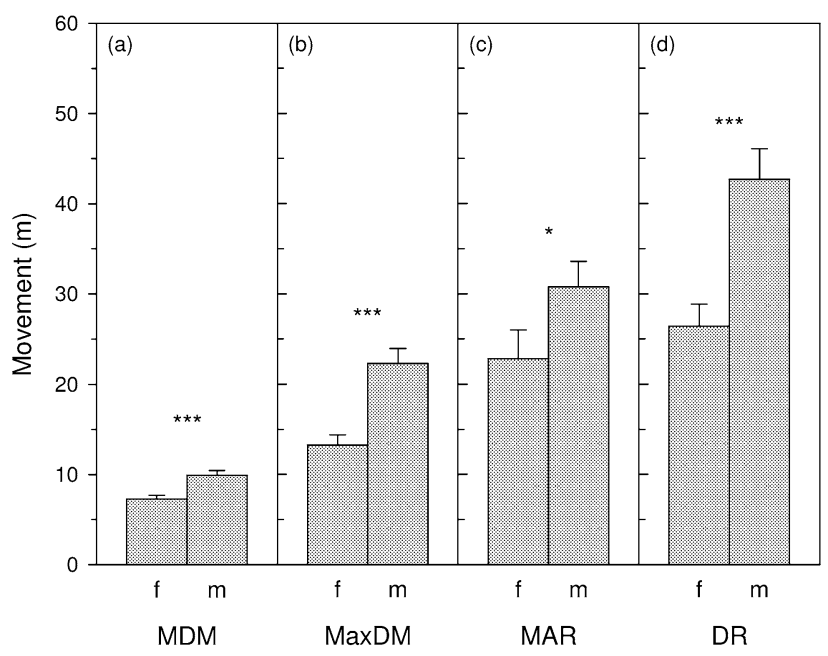

Fig. 4. Differences in the movement parameters recorded for females $(\mathrm{f})\left(\mathrm{n}_{\text {sample size }}=49\right)$ and males $(\mathrm{m})\left(\mathrm{n}_{\text {sample size }}=77\right)$. Independent $t$ test for differences: $* P<0.05, * * * P<0.001$. For abbreviations see Table 1 .

al., 1998; Diekötter et al., 2005, 2007). Marking with reflective material has resulted in day-to-day percentages of individuals seen again of more than $80 \%$ (Hein et al., 2003; Heidinger et al., 2009). A more or less steady decrease in the percentage seen again over time (Hein et al., 2003; Diekötter et al., 2007) due to mortality and emigration (Heller \& von Helversen, 1990; Narisu et al., 1999) is typical. The loss of the marks, which is common when reflective material is fixed to the femur (Heller \& von Helversen, 1990; Hein et al., 2003), was not observed during this study and is thus unlikely to have affected the results.

The percentages of marked individuals seen again were low at HE2, possibly a result of low habitat quality, which can affect patterns of movement and the likelihood of marked individuals being seen again (Gardiner \& Hill, 2004). In the case of HE2, the lack of hiding sites in the low-growing vegetation might even have lead to a higher predation rate as recorded in other studies (Hein et al., 2003; Diekötter et al., 2007). Carrion crows (Corvus corone), in particular, were often observed foraging at this site and were more abundant there than at any of the other release sites.

\section{Patterns of movement of long-winged and short-winged individuals}

Even though long-winged individuals are able to fly (Smith, 2007; Gardiner, 2008) the pattern of movement of both long- and short-winged individuals were similar. This surprising result indicates that most of the longwinged individuals that were seen again did not use their wings to fly. There are several possible reasons for this behaviour: (i) unfavourable weather conditions, which prevented them from flying (cf. Köhler, 2002). During this study there were periods when the maximum temperatures went above $25^{\circ} \mathrm{C}$, however, it is unknown if this is sufficient to induce flight. Secondly (ii), the bushcrickets did not experience crowding during this study, 

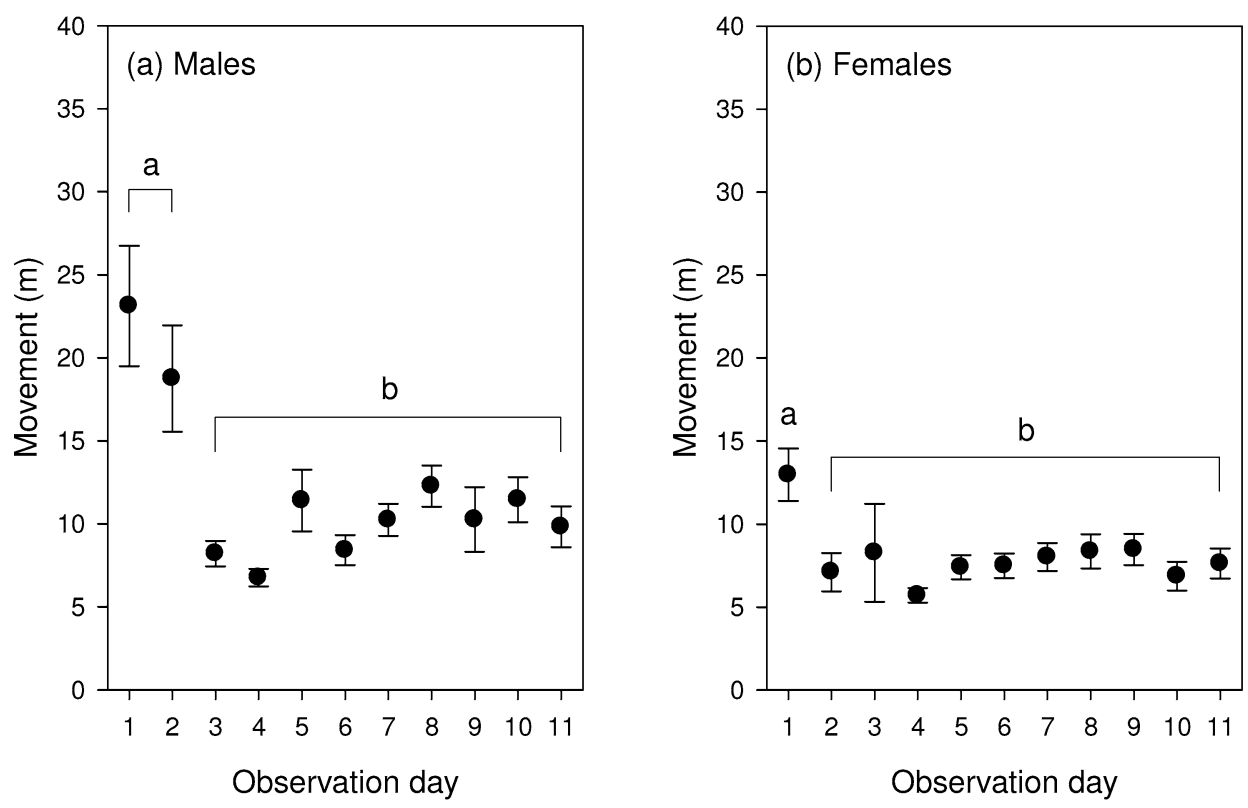

Fig. 5. Mean movement per day ( \pm SE), measured over 11 consecutive days, for (a) males and (b) females. Error bars capped with different letters indicate significant differences (analyzed using GLM with a quasi-Poisson error structure).

population densities were only high on the first day after release, after which the bush-crickets were well-distributed and moved little. Thirdly (iii), the wing muscles were non-functional, it is conceivable that some longwinged $M$. roeselii histolyze their flight muscles, as recorded for Gryllidae (cf. Shiga et al., 1991; Zera et al., 1997); i.e. they were flightless because prior to the experiment they flew and then switched to investing the energy obtained from food, almost exclusively, to reproduction (Mole \& Zera, 1993; Tanaka \& Suzuki, 1998).

However, the comparatively low number of longwinged individuals that were seen again indicates a high

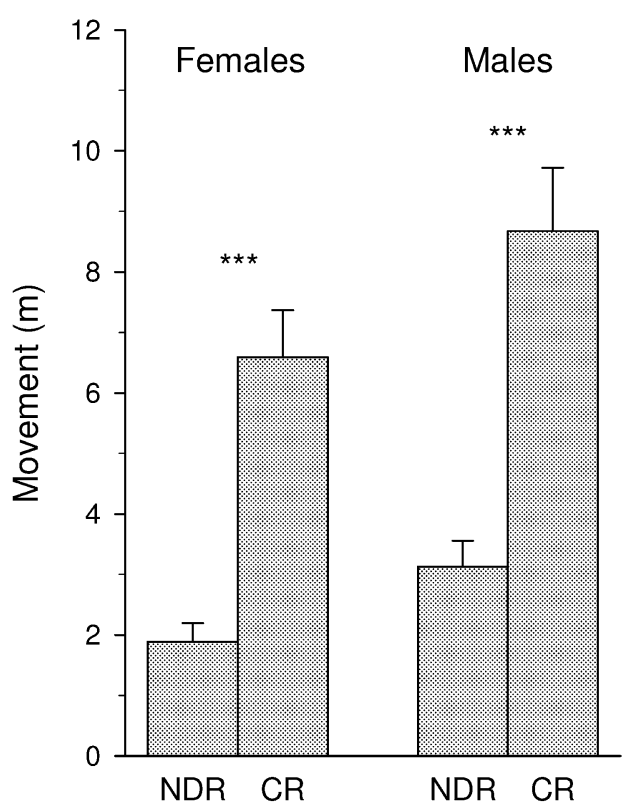

Fig. 6. Comparison of the net displacement rate (NDR) and crowding rate $(\mathrm{CR})$ for females $(\mathrm{n}=38)$ and males $(\mathrm{n}=67)$. Dependent $t$ test for differences: ${ }^{* * *} P<0.001$. dispersal potential of at least some long-winged bushcrickets (Fig. 3). This assumption is supported by many observations of long-winged individuals at locations far from the nearest population (e.g. Gardiner, 2009; Wissmann et al., 2009; Poniatowski, pers. observ.). Genetic analyses by Hochkirch \& Damerau (2009) reveal that some long-winged individuals of $M$. roeselii move up to $19 \mathrm{~km}$ from source populations. In conclusion, sedentary long-winged individuals have the same mobility as shortwinged individuals, but some macropters probably disperse over long-distances and colonize other suitable habitats.

\section{Patterns of movement of males and females}

The density-dependent dispersal documented for $M$. roeselii, is common in many taxa (Lambin et al., 2001) and recorded for the sibling species, M. brachyptera (Brunzel, 2002): crowded individuals are more mobile than unstressed individuals. However, the results of this study reveal that the effect of crowding lasts only for a short time after release; in females just for the first day and males for the first two days. After that a high percentage of the marked insects had dispersed into the surrounding area and the densities at the release point declined to a level when they no longer experienced crowding. That the locomotory behaviour in response to crowding of the different sexes differs, accords with that recorded by Diekötter et al. (2005). According to their study, when males are crowded they have a stronger tendency to avoid each other than females. However, these sex-specific differences were not only observed in crowded but also in un-crowded situations where the individuals were more evenly distributed (Fig. 4: MDM and MaxDM).

That the males were more mobile than females accords with the results of many other studies and is a common phenomenon in Orthoptera (Mason et al., 1995; Samietz 
et al., 1996; Maes et al., 2006; Walters et al., 2006; Heidinger et al., 2009). However, there are several studies that record no differences between sexes (Kindvall, 1999; Brunzel, 2002; Diekötter et al., 2005), including the study on M. roeselii carried out by Kindvall et al. (1998). At 9.0 $\mathrm{m}$ for males and $7.8 \mathrm{~m}$ for females, the mean daily movement values recorded by Kindvall et al. (1998), however, are similar to the results presented here (males: $9.9 \mathrm{~m}$, females: $7.3 \mathrm{~m}$ ).

One reason for the different patterns of movement could be differences in the sex-specific behaviour after mating. Males might be more mobile because they search for unmated females in order to increase the likelihood of producing offspring. In contrast, females, once mated, usually can find all the resources they need, such as oviposition sites, close by. Moreover, acoustic interactions may play a crucial role (Berggren, 2005). Although male singing functions primarily to attract females (Gwynne, 2001), it has also a strong influence on the behaviour of other males (Weidemann et al., 1990; Berggren, 2005). One reason might be acoustic interference (Latimer, 1981). Weak-singing individuals whose songs are superposed by those of other individuals tend to leave the proximity of dominant males (Bailey \& Morris, 1986). In addition to social interactions, the body weight of the sexes might affect mobility (Mason et al., 1995; Walters et al., 2006). Females of $M$. roeselii are generally larger and thus heavier than males, particularly when they are gravid. However, the stronger tendency of males to disperse may also be an inherent behavioural trait (Walters et al., 2006). In conclusion, the sex-specific locomotory behaviour of $M$. roeselii has probably different causes. It might depend on a complex series of social interactions and physiological conditions.

ACKNOWLEDGEMENTS. We are very grateful to J. Enderle, I. Kämpf, B. Krämer and A. Meyer (Münster) for their help with the field work. Many thanks go to T. Prinz and P. Sulmann (University of Münster) for technical support. Moreover, we would like to thank two anonymous reviewers for helpful comments on the manuscript. The Akademie für ökologische Landeserforschung e.V. partly funded the study.

\section{REFERENCES}

BAILEY W.J. \& Morris G.K. 1986: Confusion of phonotaxis by masking sounds in the bushcricket Conocephalus brevipennis (Tettigoniidae: Conocephalinae). Ethology 73: 19-28.

Bates D., Maechler M. \& Dai B. 2008: lme4: Linear mixedeffects models using $\mathrm{S} 4$ classes. $\mathrm{R}$ package version 0.999375-28. http://lme4.r-forge.r-project.org/.

BERGGREN Å. 2004: Impact of grazing on individual male movement in Roesel's bush-cricket Metrioptera roeseli: One possible clue to species range expansion. J. Insect Behav. 17: 419-429.

BERGGREN Å. 2005: The effect of conspecifics on individual male movement in Roesel's bush cricket, Metrioptera roeseli. Ecol. Entomol. 30: 480-483.

Berggren Å., Birath B. \& Kindvall O. 2002: Effect of corridors and habitat edges on dispersal behavior, movement rates and movement angels in Roesel's bush-cricket Metrioptera roeseli. Conserv. Biol. 16: 1-8.
BRUNZEL S. 2002: Increased dispersal rates and distances in density-stressed bush crickets (Metrioptera brachyptera (L., 1761)) (Saltatoria: Tettigoniidae). Beitr. Entomol. 52: 241-253.

Crawley M.J. 2007: The R Book. Wiley, Chichester, 942 pp.

Diekötter T., Csencsics D., Rothenbühler C., Billeter R. \& EDWARDS P.J. 2005: Movement and dispersal patterns in the bush cricket Pholidoptera griseoaptera: the role of developmental stage and sex. Ecol. Entomol. 30: 419-427.

Diekötter T., Speelmans M., Dusoulier F., van Wingerden W.K.R.E., Malfait J.P., Crist T.O., Edwards P.J. \& Dietz H. 2007: Effects of landscape structure on movement patterns of the flightless bush cricket Pholidoptera griseoaptera. Environ. Entomol. 36: 90-98.

FARTMANN T. 2004: Hydrochorie und warme Jahre - sind das die Gründe für die Ausbreitung der Langflügeligen Schwertschrecke (Conocephalus fuscus) in Ostbrandenburg? Articulata 19: 75-90.

Fleischer K., Streitberger M. \& Fartmann T. 2010: Die Ökologie der Wiesen-Glockenblume (Campanula patula) und des Echten Tausendgüldenkrauts (Centaurium erythraea) im Magergrünland. Tuexenia 30: 209-229.

GARDINER T. 2008: Orthoptera and allied insects of Essex 2007. Essex Nat. (N.S.) 25: 72-75.

GARDINER T. 2009: Macropterism of Roesel's bushcricket Metrioptera roeselii in relation to climate change and landscape structure in eastern England. J. Orthopt. Res. 18: 95-102.

GARDINER T. \& HiLl J. 2004: Directional dispersal patterns of Chorthippus parallelus (Orthoptera: Acrididae) in patches of grazed pastures. J. Orthopt. Res. 13: 135-141.

GwYnNe D.T. 2001: Katydids and Bush-Crickets: Reproductive Behavior and Evolution of the Tettigoniidae. Cornell University Press, New York, 317 pp.

HaRrison R.G. 1980: Dispersal polymorphisms in insects. Annu. Rev. Ecol. Syst. 11: 95-118.

Heidinger I.M.M., Poethre H.-J., Bonte D. \& Hein S. 2009: The effect of translocation on movement behaviour - A test of the assumptions of behavioural studies. Behav. Proc. 82: $12-17$.

Hein S., Gombert J., Hovestadt T. \& Poethke H.-J. 2003: Movement patterns of the bush cricket Platycleis albopunctata in different types of habitat: matrix is not always matrix. Ecol. Entomol. 28: 432-438.

Heller K.-G. \& von Helversen O. 1990: Survival of a Phaneropterid bush-cricket studied by a new marking technique (Orthoptera: Phaneropteridae). Entomol. Gen. 15: 203-208.

Hickling R., Roy D.B., Hill J.K. \& Thomas C.D. 2005: A northward shift of range margins in British Odonata. Global Change Biol. 11: 502-506.

HigAKI M. \& ANDo Y. 2003: Effects of crowding and photoperiod on wing morph and egg production in Eobiana engelhardti subtropica (Orthoptera: Tettigoniidae). Appl. Entomol. Zool. 38: 321-325.

HochKirch A. \& DAMERAU M. 2009: Rapid range expansion of a wing-dimorphic bush-cricket after the 2003 climatic anomaly. Biol. J. Linn. Soc. 97: 118-127.

InGRISCH S. \& KöHLER G. 1998: Die Heuschrecken Mitteleuropas. Westarp Wissenschaften, Magdeburg, 460 pp.

Kindvall O. 1999: Dispersal in a metapopulation of the bush cricket, Metrioptera bicolor (Orthoptera: Tettigoniidae). $J$. Anim. Ecol. 68: 172-185.

Kindvall O., Vessby K., Berggren Å. \& Hartman G. 1998: Individual mobility prevents an Allee effect in sparse populations of the bush cricket Metrioptera roeselii: an experimental study. Oikos 81: 449-457. 
Kleukers R.M.J.C., Decleer K., Haes E.C.M., Kolshorn P. \& Thomas B. 1996: The recent expansion of Conocephalus discolor (Thunberg) (Orthoptera: Tettigoniidae) in western Europe. Entomol. Gaz. 47: 37-49.

Kleukers R.M.J.C., van NieuKerken E.J., Odé B., Willemse L.P.M. \& VAN WINGERDEN W.K.R.E. 1997: De sprinkhanen en krekels van Nederland (Orthoptera). Nederlandse Fauna 1. Nationaal Natuurhistorisch Museum, KNNV Uitgeverij \& EIS-Nederland, Leiden, $415 \mathrm{pp}$.

KoČÁrek P., Holuša J., Vlk R., Marhoul P. \& Zuna-Kratky T. 2008: Recent expansions of the bush-crickets Phaneroptera falcata and Phaneroptera nana (Orthoptera: Tettigoniidae) in the Czech Republic. Articulata 23: 67-75.

KöHLER G. 2002: Experimente und Erhebungen zur Flügligkeit beim Gemeinen Grashüpfer, Chorthippus parallelus (Zetterstedt) (Caelifera: Acrididae) - ein Beitrag zur Interpretation von Makropterie. Articulata 17: 1-19.

Lambin X., Aars J. \& Piertney S. B. 2001: Dispersal, intraspecific competition, kin competition and kin facilitation: a review of the empirical evidence. In Clobert J., Danchin E., Dhondt A.A. \& Nichols J.D. (eds): Dispersal. Oxford University Press, New York, pp. 110-122.

LATIMER W. 1981: Acoustic competition in bush crickets. Ecol. Entomol. 6: 35-45.

Leisnham P.T. \& Jamieson I.G. 2002: Metapopulation dynamics of a flightless alpine insect Hemideina maori in a naturally fragmented habitat. Ecol. Entomol. 27: 574-580.

MaAs S., Detzel P. \& Staudt A. 2002: Gefährdungsanalyse der Heuschrecken Deutschlands. Verbreitungsatlas, Gefährdungseinstufung und Schutzkonzepte. Bundesamt für Naturschutz, Bonn-Bad Godesberg, 401 pp.

Maes D., Ghesquiere A., Logie M. \& Bonte D. 2006: Habitat use and mobility of two threatened coastal dune insects: implications for conservation. J. Insect Conserv. 10: 105-115.

Marshall J.A. \& HaEs E.C.M. 1988: Grasshoppers and Allied Insects of Great Britain and Ireland. Harley, Colchester, 252 pp.

Mason P.L., Nichols R.A. \& Hewitt G.M. 1995: Philopatry in the alpine grasshopper, Podisma pedestris: a novel experimental and analytical method. Ecol. Entomol. 20: 137-145.

Mole S. \& ZeRA A.J. 1993: Differential allocation of resources underlies the dispersal-reproduction trade-off in the wingdimorphic cricket, Gryllus rubens. Oecologia 93: 121-127.

NARISU, Lockwood J.A. \& Schell S.P. 1999: A novel markrecapture technique and its application to monitoring the direction and distance of local movements of rangeland grasshoppers (Orthoptera: Acrididae) in the context of pest management. J. Appl. Ecol. 36: 604-617.

Parmesan C., Ryrholm N., Stefanescu C., Hill J.K., Thomas C.D., Descimon H., Huntley B., Kaila L., Kullberg J., Tammaru T., Tennent W.J., Thomas J.A. \& Warren M. 1999: Poleward shifts in geographical ranges of butterfly species associated with regional warming. Nature 399: 579-583.

Poniatowski D. \& Fartmann T. 2005: Die Ökologie von Roesels Beißschrecke (Metrioptera roeselii) im Feuchtgrünland der Medebacher Bucht (Südwestfalen). Articulata 20: 85-111.

Poniatowski D. \& Fartmann T. 2008: Massenvorkommen makropterer Roesels Beißschrecken (Metrioptera roeselii) im Sommer 2007. Articulata 23: 53-56.
Poniatowski D. \& Fartmann T. 2009: Experimental evidence for density-determined wing dimorphism in two bush-crickets (Ensifera: Tettigoniidae). Eur. J. Entomol. 106: 599-605.

Poniatowski D. \& Fartmann T. 2011: Weather-driven changes in population density determine wing dimorphism in a bushcricket species. Agric. Ecosyst. Environ. Doi: 10.1016/ j.agee.2010.10.006.

Ramme W. 1931: Verlust oder Herabsetzung der Fruchtbarkeit bei macropteren Individuen sonst brachypterer Orthopterenarten. Biol. Zbl. 51: 533-540.

R Development Core Team 2009: $R$ : a language and environment for statistical computing. http://www.R-project.org.

Reinhardt K., Köhler G., Maas S. \& Detzel P. 2005: Low dispersal ability and habitat specificity promote ectinctions in rare but not in widespread species: the Orthoptera of Germany. Ecography 28: 593-602.

SAMIETZ J. \& Berger U. 1997: Evaluation of movement parameters in insects - bias and robustness with regard to resight numbers. Oecologia 110: 40-49.

SAmietz J., Berger U. \& KöHLer G. 1996: A population vulnerability analysis of the stripe-winged grasshopper, Stenobothrus lineatus (Caelifera: Acrididae). In Settele J., Margules C.R., Poschold P. \& Henle K. (eds): Species Survival in Fragmented Landscapes. Kluwer Academic Publishers, Dordrecht, pp. 299-311.

SChUHMACHER O. \& Fartmann T. 2003: Wie mobil ist der Warzenbeißer? Eine populationsökologische Studie zum Ausbreitungsverhalten von Decticus verrucivorus. Natursch. Landschaftspl. 35: 20-28.

Shiga S., Kogawauchi S., Yasuyama K. \& Yamaguchi T. 1991: Flight behaviour and selective degeneration of flight muscles in the adult cricket (Gryllus bimaculatus). J. Exp. Biol. 155: 661-667.

Simmons A.D. \& Thomas C.D. 2004: Changes in dispersal during species' range expansions. Am. Nat. 164: 378-395.

Sмiтн G. 2007: Bush crickets on the menu. Essex Field Club Newsletter 54: 8-9.

TANaKa S. \& SuZuKi Y. 1998: Physiological trade-offs between reproduction, flight capability and longevity in a wingdimorphic cricket, Modicogryllus confirmatus. J. Insect Physiol. 44: 121-129.

Walters R.J., Hassall M., Telfer M.G., Hewitt G.M. \& PaluTIKOF J.P. 2006: Modelling dispersal of a temperate insect in a changing climate. Proc. R. Soc. (B) 273: 2017-2023.

Weidemann S., Stiedl O. \& Kalmring K. 1990: Distribution and population density of the bushcricket Decticus verrucivorus in a damp-meadow biotope. Oecologia 82: 369-373.

Wissmann J., Schielzeth H. \& Fartmann T. 2009: Landscapescale expansion of Roesel's bush-cricket Metrioptera roeselii (Orthoptera: Tettigoniidae) at the north-western range limit in central Europe. Entomol. Gen. 31: 317-326.

Zera A.J. \& Denno R.F. 1997: Physiology and ecology of dispersal polymorphism in insects. Annu. Rev. Entomol. 42: 207-230.

Zera A.J., Sall J. \& Grudzinski K. 1997: Flight-muscle polymorphism in the cricket Gryllus firmus: muscle characteristics and their influence on the evolution of flightlessness. Physiol. Zool. 70: 519-529.

Received September 6, 2010; revised and accepted November 25, 2010 